\title{
KEDUDUKAN HUKUM SEBAGAI ALAT PEMBANGUNAN EKONOMI DI ERA REFORMASI
}

\section{Afifah Kusumadara ${ }^{1}$}

\section{Abstrak}

The fall of the New Order government together with the economic collapse in 1998 gave us the lesson of the important role of law for the economic development. The impressive economic growth developed by the New Order government could not last long and collapsed quickly because the economic development was not supported by good legal system and proper law enforcement. This phenomenon confirms the theory about the role of law as a tool of economic development. Law can bring economic efficiency in a country and give certainty which is essential for any economic player. This article will analyze whether the Reform Government has used law as a tool for economic development after the 1998 economic crisis. The analysis will discuss the efforts of the Reform government to apply law as a tool for economic development and the barriers for their effort. The conclusion of this article will recommend actions that must be done by the Reform government to improve Indonesian economy by using law as the tool of development.

Kata kunci: hukum, ekonomi, reformasi, peranan hukum, pembangunan ekonomi

\section{Pendahuluan}

Kejatuhan Pemerintahan Orde Baru bersamaan dengan runtuhnya perekonomian Indonesia di tahun 1998 memberikan pelajaran bagi bangsa Indonesia akan pentingnya hukum dalam proses pembangunan ekonomi Indonesia. Pembangunan ekonomi tanpa disertai dengan penegakan hukum mengakibatkan hancurnya ekonomi Indonesia dalam waktu yang singkat.

1 Penulis adalah dosen tetap pada Fakultas Hukum Universitas Brawijaya untuk kelompok mata-kuliah Hukum Ekonomi. Alamat korespondensi: akusumad@yahoo.com

Versi bahasa Inggris dari artikel ini telah dipresentasikan di Indonesia Council Open Conference 2009 di University of Sydney, Australia. Untuk keperluan penerbitan di Jurnal Hukum \& Pembangunan, penulis telah melakukan beberapa revisi dengan memasukkan datadata yang paling akhir. 
Pada September 1993, dalam laporan Bank Dunia berjudul A World Bank Policy Research Report, The East Asian Miracle: Economic Growth and Public Policy (selanjutnya disebut World Bank Report 1993), Indonesia mendapatkan pujian dari Bank Dunia sebagai salah satu keajaiban ekonomi Asia Timur. ${ }^{2}$ Indonesia mendapatkan predikat tersebut karena tingginya tingkat pertumbuhan ekonomi di Indonesia sejak tahun 1980-an. Akan tetapi, kurang dari empat tahun setelah World Bank Report 1993 tersebut, Indonesia mengalami krisis ekonomi parah yang dipengaruhi oleh krisis keuangan di Asia di pertengahan tahun 1997. Berbeda dari negara-negara tetangga, seperti Malaysia dan Singapura yang mampu bertahan dari krisis keuangan Asia ini, Indonesia mengalami kehancuran ekonomi yang masih dirasakan akibatnya sampai sekarang ini. Produk Domestik Bruto (PDB) Indonesia yang tumbuh rata-rata di atas $7 \%$ setahun $^{3}$ sebelum krisis keuangan Asia, terkontraksi sebesar 13,7\% di tahun 1998, dan di tahun 1999 pertumbuhan PDB Indonesia hanya mencapai $0,3 \%$. Kehancuran ekonomi Indonesia ini mengakhiri era Pemerintahan Orde Baru di bulan Mei 1998. Sampai saat ini, pertumbuhan ekonomi Indonesia belum bisa menyamai tingkat pertumbuhan ekonomi sebelum krisis. Disamping itu, Indonesia masih menghadapi problem meningkatnya angka pengangguran dan jumlah penduduk miskin. ${ }^{4}$

Hancurnya perekonomian Indonesia secara cepat di tahun 1997-1998 menguatkan argumen banyak ahli yang berpendapat bahwa pertumbuhan ekonomi Indonesia yang tinggi sebelum krisis ekonomi mengandung banyak kelemahan. Kelemahan yang terutama adalah pertumbuhan ekonomi Indonesia tidak didukung dengan sistem hukum dan penegakan hukum untuk mengontrol praktek-praktek kegiatan ekonomi yang tidak etis dan merusak fundamen perekonomian.

Prof. Iwan Jaya Azis dalam komentarnya terhadap World Bank Report 1993 menyatakan bahwa pertumbuhan ekonomi Indonesia yang tinggi tidak berarti bahwa ekonomi Indonesia efisien. Menurut beliau, ekonomi di Indonesia yang tidak efisien disebabkan tidak adanya aturan hukum yang transparan untuk mengontrol praktek-praktek rent-seeking seperti monopoli

${ }^{2}$ Indonesia mendapatkan predikat tersebut bersama-sama dengan Jepang, Hong Kong, Singapura, Taiwan, Korea Selatan, Thailand, dan Malaysia.

3 "A World Bank Policy Research Report, The East Asian Miracle: Economic Growth and Public Policy", (New York: Oxford University Press, 1993) in, "Indonesia, Satu dari Delapan Negara dengan Keajaiban Pertumbuhan Ekonomi", KOMPAS, 18 Oktober 1993, hal. 1 .

${ }^{4}$ Faisal Basri dan Haris Munandar, "Lanskap Ekonomi Indonesia", (Jakarta: Kencana, 2009), hal. 3 dan 6. 
dan oligopoli. Praktek rent-seeking ini mengakibatkan kegiatan usaha tidak berjalan pada skala biaya yang minimum dan seefisien mungkin, yang pada akhirnya menciptakan perekonomian biaya tinggi (high-cost economy) yang membebani semua pelaku usaha dan menurunkan produktivitas mereka. Ekonomi yang tidak efisien dan berbiaya tinggi ini mengakibatkan penurunan daya saing ekonomi Indonesia terutama di tingkat dunia.

Selain mengakibatkan perekonomian yang tidak efisien dan berbiaya tinggi, masalah lemahnya penegakan hukum juga mengakibatkan tingginya tingkat ketidak-pastian dalam melakukan kegiatan usaha di Indonesia. Padahal dalam kenyataannya, setiap pelaku usaha selalu membutuhkan iklim berusaha yang dapat diprediksi (predictable) dan diperhitungkan (calculable) untuk menentukan untung-rugi usaha mereka. Menurut Prof. Charles Himawan, tingginya ketidak-pastian dalam melakukan usaha di Indonesia disebabkan karena keadaan penegakan hukum dan sistem peradilan di Indonesia yang sangat buruk. Banyak putusan-putusan pengadilan yang tidak menghormati kesepakatan yang telah dibuat oleh pelaku bisnis, misalnya putusan pengadilan yang mengesampingkan pilihan hukum dan pilihan arbitrase para pihak. Ketidak-pastian hukum juga disebabkan karena seringnya pengadilan menolak untuk mengeksekusi perjanjian-perjanjian kredit yang telah disepakati para pihak. Keadaan ini mengakibatkan ketidakefisienan dan ketidak-pastian dalam melakukan kegiatan usaha di Indonesia karena tidak adanya cara yang efektif bagi pelaku usaha untuk melaksanakan kontrak bisnis mereka, untuk menagih hutang, untuk mengeksekusi agunan, dan untuk menggugat pailit. ${ }^{6}$

Pendapat Prof. Iwan Jaya Azis maupun Prof. Charles Himawan ini membenarkan teori tentang peranan penting hukum dalam pembangunan ekonomi yang sudah disuarakan oleh para pakar Law and Economics (Hukum dan Ekonomi), seperti Max Weber, David D. Friedman dan Richard Posner. Max Weber, sosiolog Jerman, dalam bukunya yang terkenal Die Protestantische Ethik und der 'Geist' des Kapitalismus (Etika Protestan dan Spirit Kapitalisme) menegaskan bahwa hukum yang rasional menjadi dasar dari pembangunan ekonomi karena dengan hukum yang rasional, pelaku

${ }^{5}$ Ekonomi Negara Tumbuh Tinggi Belum Cerminkan Adanya Efisiensi, KOMPAS, 21 October 1993, hal. 1. Lihat juga: Makna Pertumbuhan Tinggi Tetapi Tidak Efisien, KOMPAS, 22 October 1993, hal. 4.

${ }^{6}$ Ch. Himawan, Hukum Macet. Penyebab Utama Kredit Macet, KOMPAS, 5 dan 6 Agustus 1993, hal. 4. Lihat juga: Era Masyarakat Industri Juga Perlu Jaminan Kepastian Hukum, KOMPAS, 15 September 1995, hal. 13. Lihat juga: Ch. Himawan, Mercu Suar Hukum Bagi Pelaku Ekonomi (Bagian II), dari <http://www.kompas.com/9804/21/EKONOMI/ merc09.html>, diakses tanggal 21 April 1998. 
usaha dapat memprediksi dan mengkalkulasikan aktivitas ekonominya sehingga memberikan kepastian berusaha (certainty) yang sangat dibutuhkan oleh setiap pelaku usaha. ${ }^{7}$ Sedangkan Richard Posner penulis buku Economic Analysis of Law dan David D. Friedman percaya bahwa sistem hukum yang baik justru dapat meningkatkan efisiensi dalam perekonomian sehingga mengurangi biaya ekonomi (economic cost) dan biaya sosial (social cost) yang harus ditanggung pelaku usaha. ${ }^{8}$

Selanjutnya artikel ini akan menganalisa apakah di era Pemerintahan Reformasi, pemerintah telah menjadikan hukum sebagai alat dalam pembangunan ekonomi khususnya untuk memulihkan perekonomian Indonesia yang hancur akibat krisis moneter 1997.

\section{Analisa}

\section{A. Reformasi Hukum}

Pemerintahan pasca Orde Baru dikenal dengan nama Pemerintahan Reformasi, dengan harapan agar pemerintah yang baru ini membawa perubahan (reformasi) dari sistem pemerintahan yang otoriter, tidak menghargai hukum dan HAM, penuh dengan korupsi, kolusi, dan nepotisme (KKN), menjadi pemerintahan yang demokratis, menghormati prinsip Rule of Law, dan bersih dari KKN. Sudah ada empat Presiden sejak dimulainya era Reformasi di bulan Mei 1998, yaitu B.J. Habibie, Abdurrahman Wahid, Megawati Sukarnoputri, and Susilo Bambang Yudhoyono.

Salah satu reformasi hukum yang penting dalam era Pemerintahan Reformasi adalah diundangkannya berbagai perundangan di bidang otonomi daerah. Peraturan perundangan di bidang otonomi daerah ini dimaksudkan untuk membagi kewenangan pemerintahan dan pengelolaan kekayaan negara antara pemerintah pusat dengan

7 Max Weber, "Die Protestantische Ethik und der 'Geist' des Kapitalismus", (1905) diterjemahkan oleh Talcott Parsons, "The Protestant Ethic and the Spirit of Capitalism", (New York: Dover Publications, 2003), lihat juga: David M. Trubek, "Max Weber on Law and the Rise of Capitalism", Wisconsin Law Review 3 (1972): 720-753.

${ }^{8}$ Richard A. Posner, Economic, Analysis of Law, $7^{\text {th }}$ ed. (Wolters Kluwer Law \& Business, 2007), lihat juga: David D. Friedman, Law and Economics, 2002, dari $<$ http://www.econlib.org/library/Encl/LawandEconomics.html>, diakses tanggal 27 Maret 2010. Lihat juga: Johnny Ibrahim, "Pendekatan Ekonomi Terhadap Hukum. Teori dan Implikasi penerapannya dalam Penegakan Hukum", (Surabaya: CV. Putra Media Nusantara \& ITS Press, 2009). 
pemerintah provinsi, kabupaten dan kota di Indonesia. Sistem pemerintahan yang desentralisasi ini jelas merupakan sesuatu yang kontras dengan sistem pemerintahan di era Orde Baru yang semuanya dipusatkan di tangan Pemerintahan Soeharto.

Reformasi hukum penting lainnya yang dilakukan oleh Pemerintahan Reformasi adalah diundangkannya berbagai peraturan di bidang ekonomi yang sebelumnya selalu ditentang oleh Presiden Soeharto. Sebagai syarat untuk memperoleh paket bantuan keuangan IMF, IMF mewajibkan Pemerintah Indonesia untuk mengundangkan beberapa hukum ekonomi, seperti ${ }^{9}$ : Undang-undang larangan monopoli; Undang-undang pemberantasan korupsi; Undang-undang yang memberikan independensi pada Bank Indonesia agar terbebas dari intervensi pemerintah; Undang-undang Kepailitan untuk melindungi para kreditor asing dan mempercepat pelunasan hutang perusahaan-perusahaan Indonesia yang bangkrut akibat krisis ekonomi; dan Undang-undang Migas untuk mereformasi sektor energi Indonesia yang tidak efisien. ${ }^{10}$ Sebagai bagian dari reformasi di bidang hukum kepailitan, IMF menghendaki Pemerintah Indonesia untuk membentuk Pengadilan Niaga. ${ }^{~}$

\section{B. Hambatan-hambatan dalam Reformasi Hukum yang Menghambat Pembangunan Ekonomi}

Walau telah dilakukan reformasi hukum besar-besaran oleh Pemerintahan Reformasi, akan tetapi reformasi hukum ini tidak dapat menghentikan investor asing dari menutup pabriknya di Indonesia dan merelokasi pabriknya ke negara-negara tetangga Indonesia. Di era Pemerintahan Reformasi, jumlah investor asing yang meninggalkan Indonesia justru semakin meningkat, termasuk investor-investor besar yang sudah lama berinvestasi di Indonesia, seperti Sony ${ }^{12}$ dan Nike ${ }^{13}$. Disamping meningkatnya jumlah investor asing yang meninggalkan tahun 2003.

${ }^{9}$ Lihat Letter of Intent Pemerintah Indonesia kepada IMF mulai tahun 1998 sampai

${ }^{10}$ Letter of Intent Pemerintah Indonesia kepada IMF tanggal 20 Januari 2000.

${ }^{11}$ Letter of Intent Pemerintah Indonesia kepada IMF tanggal 27 August 2001.

12 “Kasus Sony Harus Dijadikan Introspeksi”, KOMPAS, 28 November 2002.

13 "Keinginan PMA Hengkang Perlu Diwaspadai", KOMPAS, 27 November 2002. 
Indonesia, era Reformasi juga mengalami penurunan drastis dari masuknya foreign direct investment ke Indonesia ${ }^{14}$. Walau ada perbaikan tingkat investasi di tahun 2003, akan tetapi tingkat investasi saat ini masih setengah dari jumlah investasi di tahun 1990an sebelum terjadinya krisis ekonomi. ${ }^{15}$ Tanpa investasi, sangat sulit bagi Pemerintahan Reformasi untuk meningkatkan pertumbuhan ekonomi Indonesia, karena investasi-lah yang membuka lapangan kerja, menumbuhkan industrialisasi dan meningkatkan kinerja ekspor.

Laporan Asian Development Bank tahun 2005 menunjuk otonomi daerah atau desentralisasi sebagai penyebab utama larinya investor asing dari Indonesia. Laporan tersebut menyebutkan adanya hubungan sebab akibat antara desentralisasi dengan ketidak-pastian dan inefisiensi dalam berbisnis di Indonesia. ${ }^{16}$ Japan External Trade Organization (JETRO) juga mengeluhkan tidak adanya kepastian hukum akibat desentralisasi, karena masing-masing daerah di Indonesia mengeluarkan peraturan, kebijakan, pajak, retribusi, prosedur perizinan, yang berbeda-beda dan berubah-rubah. ${ }^{17}$

Penerapan desentralisasi fiskal dan desentralisasi pemerintahan secara tergesa-gesa sejak Januari 2001 telah memunculkan problem ketidak-pastian hukum. Desentralisasi atau otonomi daerah memberikan peluang bagi pemerintah daerah di tingkat provinsi, kabupaten dan kotamadya untuk menerbitkan peraturan-peraturan daerah yang saling tumpang-tindih. ${ }^{18}$ Sebagai akibatnya, muncul ribuan peraturan daerah yang sebagian besar mengatur penarikan pajak dan berbagai macam pungutan untuk meningkatkan pendapatan asli daerah (PAD). ${ }^{19}$ Tendensi ini semakin diperparah dengan adanya persepsi di kalangan pemerintah daerah bahwa kesuksesan suatu pemerintah daerah ditentukan oleh besarnya PAD yang bisa mereka

14 Michael E. Porter dan Christian Ketels, "Indonesia: Attracting Foreign Investment", (Harvard Business School, 2009), hal. 15.

${ }^{15}$ Asian Development Bank, Improving the Investment Climate in Indonesia (Asian Development Bank, 2005), hal. 1.

${ }^{16}$ Asian Development Bank, Op. Cit, hal. 1-2.

${ }^{17}$ KOMPAS, 28 November 2002 Op. Cit.

18 "Hubungan Pusat-Daerah: Kewenangan Tumpang Tindih Menjadi Tidak Produktif”, KOMPAS, 22 Mei 2009, hal. 41.

${ }^{19}$ Ribuan Perda Baru yang Bikin Pusing, KOMPAS, 14 August 2003. 
peroleh. ${ }^{20}$ Tanpa adanya pembagian kewenangan yang jelas antara pemerintah tingkat provinsi, tingkat kabupaten, dan tingkat kotamadya, masing-masing pemerintah tersebut menerapkan pajak dan pungutan berulang-kali kepada para pengusaha dan investor yang beroperasi di wilayahnya. Dengan penerapan otonomi daerah, pemerintah daerah saat ini juga memiliki kewenangan untuk memberikan izin investasi di wilayahnya (kecuali untuk investasi di bidang minyak dan gas bumi). Akan tetapi, tanpa adanya prosedur perizinan investasi yang standar di daerah-daerah, proses melakukan investasi menjadi rumit, makan waktu, dan berbiaya tinggi. ${ }^{21}$ Semua peraturan daerah ini akhirnya menciptakan perekonomian yang tidak efisien, berbiaya tinggi, dan penuh ketidak-pastian, yang membuat Indonesia menjadi tempat yang tidak menarik lagi untuk berinvestasi dan berbisnis. ${ }^{22}$

Guna menghindari dampak buruk dari berbagai peraturan daerah tersebut, sejak tahun 2001 sampai dengan 2009, Menteri Keuangan telah meminta Menteri Dalam Negeri untuk membatalkan 1.651 peraturan daerah yang mengatur masalah pajak dan retribusi daerah. Menteri Keuangan beranggapan bahwa selain bertentangan dengan hirarki perundang-undangan, peraturan-peraturan daerah tersebut menciptakan ekonomi biaya tinggi. ${ }^{23}$ Sampai dengan tahun 2009, Pemerintah Pusat telah membatalkan 2.097 peraturan daerah dan masih terus mereview banyak peraturan daerah lain yang bermasalah. ${ }^{24}$

${ }^{20}$ Syaikhu Usman, et. al., Regional Autonomy and the Business Climate: Three Kabupaten Case Studies from North Sumatra, (Indonesia: SMERU, 2001), lihat juga: Syaikhu Usman, et. al., Regional Autonomy and the Business Climate: North Sulawesi and Gorontalo, (Indonesia: SMERU, 2001).

${ }^{21}$ OECD, Economic Assessment of Indonesia 2008 (OECD, 2008). Lihat juga; Asian Development Bank, Op. Cit.

${ }^{22}$ Fenomena ini membenarkan teori "Law and Economics" yang diajarkan oleh antara lain Max Weber dan Richard Posner tentang kedudukan hukum dalam pembangunan ekonomi.

23 Menteri Keuangan Minta 1.651 Perda Dibatalkan, 21 Mei 2008, dari $<$ http://www.tempointeraktif.com/hg/ekbis/2008/05/21/brk,20080521123439,id.html >, diakses tanggal 27 Maret 2010.

${ }^{24}$ Kilas Ekonomi: Pemerintah Batalkan 2.097 Peraturan Daerah, 12 November 2009, <http://cetak.kompas.com/read/xml/2009/11/12/03061151/kilas.ekonomi>, diakses tanggal 28 Maret 2010. 
Disamping disebabkan oleh desentralisasi, masalah ketidakpastian hukum dalam era Pemerintahan Reformasi juga disebabkan oleh terlalu banyaknya peraturan yang dibuat oleh Pemerintah, yang saling bertentangan satu sama lainnya. Peraturan-peraturan ini pada umumnya diterbitkan oleh kementrian-kementrian atau lembagalembaga negara yang tidak melakukan koordinasi di antara mereka. Terlalu banyaknya peraturan memaksa pelaku usaha untuk memberikan biaya tidak resmi dan suap guna mempercepat proses perizinan, clearance, dan layanan pemerintah lainnya. ${ }^{25} \mathrm{Hal}$ ini mengakibatkan ekonomi biaya tinggi dan korupsi masih umum terjadi di Indonesia seperti di zaman Pemerintahan Orde Baru.

Sebagai contoh, peraturan-peraturan yang sangat banyak dan saling bertentangan telah mengakibatkan terjadinya praktek suap yang meluas di kantor Direktorat Jenderal Bea Cukai. Pada tanggal $30 \mathrm{Mei}$ 2008, Komisi Pemberantasan Korupsi (KPK) dalam inspeksi mendadak (sidak) di kantor Direktorat Jenderal Bea Cukai Tanjung Priok Jakarta menemukan uang suap senilai Rp. 500 juta dan menangkap basah empat Pejabat Fungsional Pemeriksa Dokumen yang menerima suap. Setelah sidak KPK tersebut, pelayanan di kantor Direktorat Jenderal Bea Cukai Tanjung Priok menjadi melambat. Pengurusan dokumen-dokumen yang biasanya dapat diselesaikan dalam waktu sehari sebelum sidak KPK, membutuhkan waktu sampai empat hari setelah sidak KPK. Penurunan percepatan pada pelayanan kepabeanan di Tanjung Priok ini sampai pada tingkat sangat mengganggu kinerja para pelaku usaha. Dalam rangka mencari solusi atas kelambatan pelayanan kepabeanan ini, Kamar Dagang dan Industri Indonesia (KADIN) menemukan bahwa Direktorat Jenderal Bea Cukai dibebani oleh lebih dari 1.000 peraturan yang melarang berbagai jenis barang dari luar negeri masuk ke wilayah pabean Indonesia. Aturan itu berasal dari berbagai macam lembaga dan departemen yang memperlambat kinerja petugas dan proses pemeriksaan barang-barang impor. Penemuan KADIN ini didukung oleh Direktur Jenderal Bea Cukai, Anwar Suprijadi yang menyatakan:'Kondisi itu menyebabkan bertambahnya alur birokrasi yang berlebihan sehingga menambah waktu dan biaya penyelesaian di pelabuhan". Sedangkan Ketua Komite Tetap Moneter dan Fiskal KADIN Bambang Soesatyo menegaskan bahwa KADIN sangat prihatin dengan adanya lebih dari 1.000 peraturan larangan pemasukan barang dari berbagai instansi itu. Aturan itu antara lain berasal dari

${ }^{25}$ Asian Development Bank, Op. Cit., hal. 36. 
Departemen Perdagangan, Badan Pengawas Obat dan Makanan, Departemen kesehatan, Departemen Pertanian, Departemen Pertahanan, Balai Karantina Hewan atau Tumbuhan, dan Departemen Pendidikan Nasional. Menurut Bambang Soesatyo, disamping sering bertentangan satu sama lainnya, ribuan peraturan tersebut sering ditulis secara tidak jelas sehingga membingungkan petugas kepabeanan dan memperlambat arus keluar masuknya barang di kepabeanan. Baik Direktur Jenderal Bea Cukai maupun KADIN sepakat bahwa peraturan yang terlalu banyak, tidak jelas maknanya, dan bertentangan satu sama lain mengakibatkan panjangnya jalur birokrasi yang tidak perlu. Salah satu jalan yang sering dilakukan pelaku usaha di Indonesia untuk memotong jalur birokrasi yang bertele-tele ini adalah dengan membayar biaya tidak resmi dan suap kepada petugas-petugas di kantor pemerintah, termasuk di Direktorat Jenderal Bea Cukai. ${ }^{26}$ Apa yang terjadi di kantor Direktorat Jenderal Bea Cukai Tanjung Priok ini menjelaskan bahwa peraturan yang terlalu banyak, tidak jelas dan bertentangan satu sama lainnya di Indonesia mengakibatkan korupsi dan ekonomi biaya tinggi.

Kebiasaan pemerintah Reformasi untuk menerbitkan peraturanperaturan yang berlaku mundur (retroactive) juga memunculkan ketidak-pastian hukum bagi investor asing maupun domestik. Peraturan-peraturan yang retroactive tersebut telah memunculkan konflik hukum antara investor dan Pemerintah.

Salah satu contohnya adalah peraturan retroactive di bidang perpajakan. Menteri Keuangan menerapkan Peraturan Pemerintah yang baru yaitu PP nomor 144 tahun 2000 tentang Jenis Barang dan Jasa yang Tidak Dikenakan Pajak Pertambahan Nilai, kepada perusahaan produsen batu-bara yang berada di bawah Perjanjian Karya Pengusahaan Pertambangan Batubara (PKP2B) generasi I. Berdasar PKP2B generasi I, batu-bara dikategorikan sebagai barang kena pajak dan produsen batu-bara memperoleh restitusi pajak pertambahan nilai (PPN) setiap tahunnya. Berdasar sistem perpajakan tetap yang disepakati pemerintah dalam PKP2B generasi I, produsen batu-bara dikenai tarif pajak perseroan jauh lebih tinggi, yakni $45 \%$ dibandingkan tarif pajak tertinggi sesuai aturan pepajakan yang hanya

26 Banyak Beban Aturan di Bea dan Cukai, 11 Juni 2008, dari $<$ http://www.kompas.com/printnews/xml/2008/06/11/04591538/banyak.beban.aturan.di.bea.c ukai>, diakses tanggal 28 Maret 2010. Lihat juga: Pelayanan BC di Priok Melambat, 20 Juni 2008 dari <http://cetak.kompas.com/printnews/xml/2008/06/20/01035247/pelayanan>, diakses tanggal 13 Agustus 2008. 
$30 \%$. Produsen batu-bara yang berada di bawah PKP2B generasi I tidak dapat menerima pemberlakuan PP nomor 144 tahun 2000 yang tidak lagi mengkatogerikan batu-bara sebagai barang kena pajak sehingga mereka tidak dapat lagi memperoleh restitusi PPN. Mereka menganggap bahwa Pemerintah telah melanggar sistem perpajakan tetap yang disepakati pemerintah dalam PKP2B generasi I. Sebagai tindakan balasan atas pelanggaran Pemerintah terhadap kesepakatan PKP2B generasi I, empat belas perusahaan produsen batu-bara tidak lagi bersedia membayar royalti dana hasil produksi batu-bara (DHPB) mereka sejak 2001 ke Pemerintah. Pada awal bulan Agustus 2008, Menteri Keuangan mengajukan permohonan cekal kepada Dirjen Imigrasi atas direktur dan komisaris empat belas perusahaan batu-bara yang menunggak royalty $\mathrm{DHPB} .{ }^{27}$ Kasus penahanan royalti yang berlanjut pada pencekalan ini menuai kontroversi karena pencekalan tersebut juga melibatkan beberapa pengusaha berkewarganegaraan asing. Hal ini memaksa Presiden Yudhoyono turun tangan menengahi sengketa antara perusahaan batu-bara dan Departemen Keuangan. Pada tanggal 13 Agustus 2008, Presiden Yudhoyono memerintahkan Menteri Keuangan dan Menteri Energi dan Sumber Daya Mineral untuk mengakhiri ketidak-pastian hukum. ${ }^{28}$ Akhirnya pada bulan Oktober 2008, Dirjen Imigrasi mencabut pencekalan atas direktur dan komisaris perusahaan batu-bara yang menunggak royalti, setelah perusahaan batu-bara mereka bersedia untuk membayar royalti batubara yang mereka tahan sejak 2001. Demikian pula, Departemen Keuangan beserta Departemen Energi dan Sumber Daya Mineral berjanji untuk membayarkan restitusi pajak PPN yang belum diterima oleh keempat belas perusahaan batu-bara tersebut. ${ }^{29}$

Contoh lain dari peraturan retroactive yang menimbulkan ketidakpastian hukum bagi investor adalah perubahan peraturan di bidang

${ }^{27}$ Dirjen Imigrasi Cekal 14 Pemimpin Perusahaan Tambang Batubara, 5 Agustus 2008, dari <http://www.kontan.co.id/index.php/nasional/news/626/DirjenImigrasi-Cekal-14Pemimpin-Perusahaan-Tambang-Batubara>, diakses tanggal 28 Maret 2010.

28 Batu Bara Membara, 11 Agustus 2008, dari <http://cetak.kompas.com/ $\mathrm{read} / \mathrm{xml} / 2008 / 08 / 11 / 00570150 /$ batu.bara.membara $>$, diakses tanggal 28 Maret 2008. Lihat juga: Royalti Batu Bara, Presiden: Hindarkan Ketidakpastian Hukum, 14 Agustus 2008, dari <http://www.kompas.com/read/xml/2008/08/14/00020617/presiden.hindarkan.ketidakpastian. hukum>, diakses tanggal 14 Agustus 2008.

29 Pencekalan Pengusaha Batu Bara Dicabut, 10 Oktober 2008, dari $<$ http://www.republika.co.id/koran/16/6793/Pencekalan_Pengusaha_Batu_Bara_Dicabut $>$, diakses tanggal 10 Oktober 2008. 
Kontrak Karya dan Perjanjian Karya bagi perusahaan pertambangan. Undang-undang Pertambangan yang baru, Undang-undang Nomor 4 Tahun 2009 tentang Pertambangan Mineral dan Batu Bara (Pertambangan Minerba), yang menggantikan Undang-undang Nomor 11 Tahun 1967 tentang Ketentuan-Ketentuan Pokok Pertambangan, memberikan posisi yang lebih kuat kepada Pemerintah Indonesia di hadapan investor produsen batu-bara. Berdasarkan undang-undang Pertambangan yang lama, Pemerintah Indonesia memiliki kedudukan yang sejajar dengan investor produsen batu bara di dalam Kontrak Karya atau Perjanjian Karya. Karena posisi yang sejajar sebagai pihak dalam Kontrak Karya atau Perjanjian Karya, Pemerintah Indonesia tidak dapat melakukan perubahan apapun terhadap Kontrak Karya atau Perjanjian Karya tanpa persetujuan pihak produsen batu-bara. Di dalam Undang-undang Pertambangan Minerba yang baru ini, Pemerintah Indonesia tidak lagi ditempatkan dalam kedudukan sejajar dengan investor produsen batu-bara, akan tetapi ditempatkan sebagai pemberi izin bagi investor untuk melakukan pengusahaan pertambangan. Dengan posisi sebagai pemberi izin, Pemerintah Indonesia akan memiliki kewenangan yang lebih kuat untuk mengatur produsen pertambangan. Oleh karena itu, pasal 169b Undang-undang Nomor 4 Tahun 2009 tentang Pertambangan Mineral dan Batu Bara mensyaratkan agar setahun setelah diundangkannya Undang-undang ini seluruh Kontrak Karya dan Perjanjian Karya yang ada digantikan dengan Izin Usaha Pertambangan (IUP). Peraturan yang berlaku mundur (retroactive) ini menimbulkan ketidak-pastian hukum terhadap status Kontrak Karya dan Perjanjian Karya yang sedang berjalan dan memaksa para pihak untuk mengubah kontrak mereka sebelum berakhirnya jangka waktu kontrak tersebut. Perhimpunan Ahli Pertambangan Indonesia (Perhapi) menilai aturan dalam pasal $169 \mathrm{~b}$ tersebut menimbulkan ketidak-pastian dan berimplikasi negatif terhadap iklim investasi pertambangan di Indonesia. Sementara itu, sekretaris perusahaan Rio Tinto Indonesia, Budi Irianto mengatakan bahwa Rio Tinto Indonesia akan mengevaluasi rencana investasi mereka dan juru bicara PT. Freeport Indonesia, Mindo Pangaribuan mengatakan bahwa baik perusahaan maupun pemerintah Indonesia hendaknya konsisten menghormati kontrak yang sedang berlaku. ${ }^{30}$

${ }^{30}$ Era Kontrak Karya Berakhir, Pengelolaan Pertambangan Lewat Perizinan, 17 Desember 2008, dari <http://cetak.kompas.com/read/xml/2008/12/17/00400686/era.kontrak. karya.berakhir>, diakses tanggal 28 Maret 2010. Lihat juga: Izin Tambang Harus Diawasi, Freeport Indonesia Akan Patuhi Kontrak, 18 Desember 2008 dari 
Kedua contoh kasus di atas menggambarkan meningkatnya ketidak-pastian hukum di era Pemerintahan Reformasi akibat penerapan peraturan yang retroactive. Hal ini memunculkan konflik antara Pemerintah dan investor, yang pada akhirnya berimplikasi negatif terhadap iklim investasi di Indonesia.

Ketidak-pastian hukum di Indonesia juga berakibat meningkatnya jumlah sengketa yang muncul antara investor asing dan Pemerintahan Reformasi atau antara investor asing dan Badan Usaha Milik Negara yang harus dibawa ke lembaga arbitrase internasional. Penyelesaian sengketa di lembaga arbitrase internasional ini sudah barang tentu memakan waktu dan biaya yang tidak terhitung banyaknya, sehingga dapat dikatakan menghamburkan uang rakyat. Beberapa sengketa tersebut diantaranya melibatkan investor-investor besar, seperti: American Caithness Energy, L.L.C. dan Florida Power and Light Company (dalam kasus Karaha Bodas Company melawan Pertamina dan PT PLN di tahun 2000); Mexican Cemex S.A. (dalam kasus Cemex Asia melawan Pemerintah Republik Indonesia di tahun 2005); American Newmont (dalam kasus PT Newmont Nusa Tenggara melawan Pemerintah Republik Indonesia di tahun 2009). Sebagian besar dari sengketa tersebut disebabkan tidak jelasnya aturan tentang prosedur divestasi di Indonesia, ditambah dengan tidak jelasnya pembagian kewenangan antara Pemerintah Pusat dan Pemerintah Daerah tentang siapa yang seharusnya bertanggung-jawab atas proses divestasi penanaman modal asing di Indonesia.

Pembangunan ekonomi di era Reformasi juga terhambat oleh sistem peradilan Indonesia yang sering mengingkari isi kontrak yang telah disepakati para pihak, tidak menghormati keputusan arbitrase dan tidak menerapkan aturan hukum sebagaimana mestinya. ${ }^{31}$ Banyak pelaku usaha, di dalam negeri maupun di luar negeri, yang beranggapan bahwa pengadilan-pengadilan di Indonesia tidak memiliki kemampuan untuk menangani kasus-kasus komersial atau perdagangan. Hal ini menyebabkan banyak keputusan pengadilanpengadilan di Indonesia tidak konsisten, memihak, dan tidak dapat diprediksi. Sistem hukum Indonesia yang buruk menempatkan Indonesia pada ranking ke 19 dari 24 negara di wilayah Asia Timur

$<$ http://cetak.kompas.com/read/xml/2008/12/18/0045163/izin.tambang.harus.diawasi $>$, diakses tanggal 26 December 2008.

${ }^{31}$ Asian Development Bank, Op. Cit., hal. 9. 
dan Pasifik, dalam hal kelancaran melakukan bisnis. ${ }^{32}$ Ranking Indonesia yang rendah ini membenarkan hasil survey yang sebelumnya dilakukan oleh Political and Economic Risk Consultancy (PERC) di tahun 2008, yang menempatkan Indonesia di ranking terbawah dari 13 negara-negara di Asia dalam hal sistem peradilannya. ${ }^{33}$

Walaupun Pemerintah Reformasi telah mendirikan Pengadilan Niaga sejak 1998 untuk menangani masalah-masalah hukum perniagaan, pengadilan ini belum dapat menjamin pemberian keputusan yang adil dan tidak memihak bagi investor asing. Keputusan-keputusan Pengadilan Niaga yang mengalahkan perusahaan-perusahaan asing di Indonesia telah menimbulkan kritik dan menguatkan pendapat umum tentang sistem peradilan Indonesia yang sewenang-wenang dan dipenuhi korupsi. Pada tahun 2002, Pengadilan Niaga memutuskan pailit PT Asuransi Jiwa Manulife Indonesia (AJMI), yang merupakan anak perusahaan dari perusahaan asuransi Kanada, Manulife Financial Corporation. PT AJMI yang didirikan pada tahun 1985, merupakan perusahaan patungan yang $51 \%$ sahamnya dimiliki oleh Manulife Financial Corporation (Manulife), $40 \%$ sahamnya dimiliki oleh perusahaan Indonesia, PT Dharmala Sakti Sejahtera (Dharmala), dan 9\% sahamnya dimiliki oleh International Finance Corporation (IFC), anak perusahaan dari World Bank Group. Komposisi kepemilikian saham ini berubah di bulan Juni 2000 sewaktu Dharmala diputuskan bangkrut oleh Pengadilan Niaga. Kemudian saham Dharmala di AJMI dibeli semua oleh Manulife Kanada. Pengambil-alihan saham Dharmala oleh Manulife ini dilakukan dengan persetujuan dari Pemerintah Indonesia dan IFC. AJMI menjadi salah satu dari tiga besar perusahaan asuransi di Indonesia yang pada tahun 2001 memperoleh keuntungan bersih sebesar Rp. 75,5 milyar, dan memiliki aset seharga US\$ 360 juta. Akan tetapi, pada bulan Juni 2002, Dharmala menggugat pailit AJMI di Pengadilan Niaga dengan alasan AJMI telah gagal membayar deviden atau keuntungan perusahaan kepada Dharmala sejak tahun 1998 sampai dengan 2000 sebesar Rp. 32,7 milyar. Dalam

32 The World Bank Group, Doing Business 2010 Report, June 2008 - May 2009. dari <http://www.doingbusiness.org/economyrankings/>, diakses tanggal 28 Maret 2010

${ }^{33}$ AFP. Hong Kong Has Best Judicial System In Asia: Business, 14 September 2008 dari <http://afp.google.com/article/ALeqM5gIkKvk-YnNQ1HVb2n_HUUMhncDLA>. diakses tanggal 27 Maret 2010. 
persidangan, AJMI berargumen bahwa mereka tidak membayarkan deviden karena terikat dengan keputusan Rapat Umum Pemegang Saham di pertengahan tahun 2000 yang memutuskan agar deviden tidak dibagikan karena situasi perekonomian Indonesia yang masih labil. Pengadilan Niaga tetap mengabulkan gugatan Dharmala dan memutus AJMI pailit dengan dasar telah terjadinya pelanggaran perjanjian joint-venture yang salah satunya menyepakati pembayaran deviden apabila AJMI memperoleh keuntungan. Atas keputusan Pengadilan Niaga tersebut, AJMI mengajukan kasasi ke Mahkamah Agung RI. Seminggu setelah dikeluarkannya keputusan Pengadilan Niaga, kurator yang ditunjuk Pengadilan Niaga memerintahkan AJMI untuk menghentikan bisnis mereka dan menutup 75 kantor cabang. Hal ini menyebabkan kepanikan pada pemegang polis asuransi AJMI. Keputusan Pengadilan Niaga ini semakin menguatkan kekuatiran para investor asing akan rendahnya kepastian hukum di Indonesia. Pemerintah Kanada mengajukan protes resmi kepada Pemerintah Indonesia atas keputusan Pengadilan Niaga tersebut. World Bank maupun International Monetary Fund juga menyatakan keprihatinannya terhadap penanganan kasus AJMI ini. Sementara IFC mulai mempertimbangkan kelangsungan investasinya di Indonesia. Mereka menguatirkan kenetralan Pengadilan Niaga dalam kasus ini dan mencurigai kemungkinan penyuapan terhadap majelis hakim untuk menjatuhkan perusahaan asing yang sehat dan menguntungkan. Ditengah-tengah tekanan masyarakat internasional, hanya satu bulan setelah dikeluarkannya keputusan Pengadilan Niaga tersebut, Mahkamah Agung RI mengabulkan permohonan kasasi AJMI dan membatalkan keputusan Pengadilan Niaga yang mempailitkan AJMI. Keputusan Mahkamah Agung ini didasarkan pada alasan teknis, bukan alasan substantif, yaitu pemohon kepailitan, Dharmala, belum memperoleh izin hakim pengawas dan para kreditor AJMI yang lain untuk menggugat pailit AJMI, sebagaimana disyaratkan dalam Undang-undang Kepailitan No. 4 tahun $1998 .^{34}$

${ }^{34}$ David K. Linnan, "Insolvency Law and Institutions in Indonesia", in "Insolvency Law in East Asia", ed. Tomasic Roman (England: Ashgate, 2006), hal. 357-358. Lihat juga: Badan Perencanaan dan Pembangunan Nasional (BAPPENAS), Lihat juga: Wapres Panggil Menkeu Soal Manulife, Depkeu Kanada Protes ke Dubes RI, 18 Juni 2002 dari $<$ http://els.bappenas.go.id/upload/other/Wapres\%20Panggil\%20Menkeu\%20soal\%20Manulife .htm>, diakses tanggal 17 Juni 2009. Lihat juga: Manulife Tak Jadi Bangkrut, 9 Juli 2002, dari, <http://www.korantempo.com/news/2002/7/9/Opini/83.html>, diakses tanggal 17 Juni 2009 
Dua tahun setelah keputusan Pengadilan Niaga yang kontroversial di atas, pada bulan April 2004 Pengadilan Niaga kembali memutuskan pailit sebuah perusahaan asuransi yang sehat dan menguntungkan, yaitu PT Prudential Life Assurance. PT Prudential Life Assurance digugat pailit oleh seorang warga negara Malaysia, Lee Boon Siong, karena PT Prudential Life Assurance tidak membayarkan bonus keagenan kepada Lee Boon Siong sebesar Rp. 1,43 miliar pada tahun 2003. Pengadilan Niaga mengabulkan gugatan kepailitan yang diajukan oleh Lee Boon Siong. Atas keputusan Pengadilan Niaga tersebut, Kedutaan Besar Kerajaan Inggris mengajukan protes, sedangkan Consultative Group on Indonesia (CGI), kelompok negaranegara dan lembaga internasional pemberi donor untuk Indonesia, menyoroti kasus ini dalam pertemuannya di Jakarta. PT Prudential Life Assurance mengajukan kasasi atas keputusan Pengadilan Niaga ke Mahkamah Agung RI. Pada bulan Juni 2004, Mahkamah Agung mengabulkan permohonan kasasi PT Prudential Life Assurance dan membatalkan keputusan Pengadilan Niaga. Mahkamah Agung berpendapat bahwa kasus Prudential melawan Lee Boon Siong bukan merupakan kasus kepailitan dan ketidak-mampuan pembayaran hutang, tetapi kasus wanprestasi perjanjian keagenan yang seharusnya diputus oleh Pengadilan Negeri bukan Pengadilan Niaga.

Belajar dari dua kasus kepailitan yang kontroversial ini, IMF meminta Pemerintah Reformasi untuk segera merevisi Undang-undang Kepailitan yang telah disalah-gunakan untuk mempailitkan dan melikuidasi perusahaan-perusahaan asing yang sehat dan menguntungkan. Pada bulan September 2004, Dewan Perwakilan Rakyat menyetujui diundangkannya Undang-undang No. 37 tahun 2004 tentang Kepailitan dan Penundaan Kewajiban Pembayaran Utang. Berdasarkan Undang-undang Kepailitan yang baru ini, kreditur tidak dapat lagi menggugat pailit perusahaan asuransi di muka Pengadilan Niaga. Hanya Menteri Keuangan yang dapat mengajukan gugatan kepailitan atas perusahaan asuransi.

Ketidak-pastian hukum di Indonesia juga mengakibatkan bankbank di Indonesia enggan memberikan kredit yang justru dibutuhkan

${ }^{35}$ Pengadilan Pailitkan Prudential Life, 23 April 2004, dari, <http://www.tempo. co.id/hg/hukum/2004/04/23/brk,20040423-35, id.html>, diakses tanggal 3 April 2010. Lihat juga: MA Kabulkan Kasasi Prudential, 8 Juni 2004, dari, <http://tempo.co.id/ hg/ekbis/2004/06/08/brk,20040608-07,id.html>, diakses tanggal 3 April 2010. Lihat juga: Prudential's Indonesian Directors Face Jail Threat Over Bankruptcy Charge," 11 Mei 2004, dari, <http://www. financialexpress.com/printer/news/59761/>, diakses tanggal 3 April 2010. 
oleh para pelaku usaha untuk menggerakkan roda ekonomi. Undangundang no. 4 Tahun 1996 tentang Hak Tanggungan Atas Tanah Beserta Benda-Benda yang Berkaitan Dengan Tanah (Undang-undang Hak Tanggungan) awalnya dimaksudkan untuk memberikan kepastian hukum bagi kreditur atau lembaga keuangan perbankan dan nonperbankan, serta debitur. Akan tetapi pada kenyataannya pelaksanaan Undang-undang Hak Tanggungan ini dihadapkan pada banyak masalah. Eksekusi hak tanggungan tidak mudah untuk dilaksanakan, bahkan beberapa lembaga pemerintah menolak untuk melakukan eksekusi hak tanggungan. ${ }^{36}$ Hal ini disebabkan karena masih diberlakukannya yurisprudensi Mahkamah Agung dan beberapa fatwa Mahkamah Agung yang dibuat jauh sebelum diundangkannya Undang-undang Hak Tanggungan ini dan isinya sudah tidak sesuai dengan undang-undang ini. Putusan Mahkamah Agung No. 3021/K/Pdt/1984, tanggal 30 Januari 1986, menyatakan bahwa lelang berdasarkan parate eksekusi (eksekusi langsung) tidak boleh dilakukan tanpa melalui fiat atau persetujuan Ketua Pengadilan Negeri. Sedang fatwa Mahkamah Agung tentang Grosse Akte No. 213/229/05/II/UmTu/Pdt tanggal 16 April 1985, No. 133/154/86/II/Um-Tu/Pdt tgl 18 Maret 1986, dan No. 147/168/86/II/Um-TU/Pdt tanggal 1 April 1986, mengharuskan bank melakukan prosedur gugatan lebih dulu di Pengadilan Negeri sebelum bank melakukan eksekusi agunan kredit macet. Yurisprudensi dan fatwa Mahkamah Agung yg masih diberlakukan walau bertentangan dengan isi dan tujuan Undangundang Hak Tanggungan ini jelas menimbulkan ketidak-pastian hukum bagi kalangan perbankan. Larangan Mahkamah Agung bagi bank untuk melakukan eksekusi hak tanggungan secara langsung, karena bank harus melewati prosedur gugatan biasa, juga menyebabkan biaya tinggi bagi kalangan perbankan. Ketidak-pastian hukum dan biaya tinggi dalam proses eksekusi agunan kredit macet, menjadi salah satu penyebab keengganan bank-bank di Indonesia untuk menyalurkan kredit bagi pelaku usaha di Indonesia.

Hal ini berakibat pada penurunan jumlah kredit yang disalurkan perbankan Indoenesia kepada perusahaan-perusahaan manufaktur. Pada tahun 1985, hampir 40\% kredit bank disalurkan ke industri manufaktur. Pada November 2009, industri manufaktur hanya memperoleh 17,2 persen dari kredit bank yang ada. Saat ini, mayoritas kredit bank disalurkan ke segmen pembiayaan konsumsi dan

${ }^{36}$ St. Laksanto Utomo, Menyoal Eksekutorial Hak Tanggungan, Antara News, 1 Januari 2009, dari, <http://www.antara.co.id/print/1230784015>, diakses tanggal 3 April 2010. 
pembangunan properti. Kalangan perbankan menganggap sektor konsumsi dan properti kurang beresiko dan jangka pengembalian investasinya lebih cepat dibandingkan dengan industri manufaktur yang beresiko tinggi dengan jangka pengembalian investasi yang lama. ${ }^{37}$

Kalangan perbankan Indonesia juga menerapkan suku bunga pinjaman yang sangat tinggi, yang berkisar antara $13 \%$ sampai $15 \%$, bahkan mencapai $17 \%$ untuk suku bunga pinjaman yang diberikan kepada pelaku usaha di sektor usaha mikro, kecil, dan menengah (UMKM), padahal Bank Indonesia telah menurunkan suku bunga patokan (BI rate) sampai serendah 6,5\% untuk mempengaruhi pasar. Suku bunga patokan Bank Indonesia ini ternyata tidak diikuti oleh kalangan perbankan Indonesia. Hal ini mengakibatkan sektor industri manufaktur sulit untuk berkembang karena mereka tertekan oleh biaya pembiayaan bank yang sangat tinggi. ${ }^{38}$ Suku bunga pinjaman yang sangat tinggi ini mungkin merupakan cara perbankan di Indonesia untuk melindungi diri mereka dari resiko kredit macet dan agunan yang tidak dapat dieksekusi akibat tidak adanya kepastian hukum di Indonesia.

Sedikit dan mahalnya pembiayaan dari bank kepada industri manufaktur menghambat produktivitas mereka. Hal ini berkontribusi terhadap fenomena deindustrialisasi yang terjadi dewasa ini. ${ }^{39}$

Fenomena deindustrialisasi yang diakibatkan tingginya suku bunga pembiayaan bank ini sangat berbahaya, karena deindustrialisasi meningkatkan jumlah pengangguran di Indonesia yang berdampak buruk pada kehidupan sosial dan politik serta mengganggu kestabilan

37 Tajuk Rencana: Deindustrialisasi Kian Nyata, 8 Oktober 2009, dari, <http://cetak.kompas.com/read/xml/2009/10/08/02461119/tajuk.rencana>, diakses tanggal 3 April 2010. Lihat juga: Membendung Gejala Deindustrialisasi, 20 Oktober 2009, dari, <http://cetak.kompas.com/read/xml/2009/10/20/05135488/membendung.gejala.deindustrialisa si>, diakses tanggal 3 April 2010. Lihat juga: Manufaktur Tak Berkembang. Ekonomi Biaya Tinggi Jadi Salah Satu Penyebab, 8 Februari 2010, dari, <http://cetak.kompas.com/ $\mathrm{read} / \mathrm{xml} / 2010 / 02 / 08 / 03282498 /$ manufaktur.tak. berkembang $>$, diakses tanggal 3 April 2010.

${ }^{38}$ Bramanian Surendro, "Perbankan Memiliki Struktur Oligopoly?", KOMPAS, 18 Mei 2009, hal. 21. Lihat juga: Faisal Basri dan Haris Munandar, Op. Cit., hal. 16-19.

${ }^{39}$ Penyebab lain dari deindustrialisasi di Indonesia adalah keterbatasan energi dan buruknya infrastruktur. Lihat dalam: Kerja Keras Untuk Tumbuh 7 Persen, 26 Oktober 2009 , dari <http://cetak.kompas.com/read/xml/2009/10/26/03245428/kerja.keras.untuk.tumbuh.7. persen>, diakses tanggal 3 April 2010. 
makro-ekonomi yang telah dicapai dengan susah payah oleh pemerintah. ${ }^{40}$ Oleh karena itu, untuk meyakinkan kalangan perbankan di Indonesia agar mereka bersedia menurunkan suku bunga pinjaman dan meningkatkan alokasi kredit ke sektor industri manufaktur, sistem hukum dan peradilan Indonesia harus dibenahi supaya bisa lebih efektif untuk menagih hutang debitur, untuk mengeksekusi agunan, dan untuk menggugat pailit. Dengan kata lain, segala aturan atau prosedur penyebab ketidak-pastian hukum dan biaya tinggi dalam proses eksekusi agunan kredit macet harus dihapuskan dalam sistem hukum dan peradilan di Indonesia.

\section{Kedudukan Hukum di Bawah Kepemimpinan Presiden Yudhoyono yang Terakhir}

Kemenangan mutlak Presiden Yudhoyono pada Pemilu 2009 untuk masa jabatan kedua sekaligus terakhirnya, ternyata telah mengurangi ambisinya untuk menumpas korupsi. Di masa jabatan terakhirnya sebagai Presiden, Yudhoyono tidak lagi merasa perlu untuk mencitrakan dirinya sebagai seorang penegak hukum karena dia tidak akan terlibat lagi dalam Pemilu Presiden yang akan datang. Setelah terpilih kembali sebagai Presiden, Yudhoyono memberikan perhatian lebih terhadap pembangunan ekonomi, dan kurang memberikan perhatian kepada menurunnya kualitas penegakan hukum dan gerakan anti-korupsi.

Sebagai bagian dari program 100 hari pertama Kabinet Indonesia Bersatu II, pada tanggal 29 Oktober 2009, Presiden Yudhoyono menyelenggarakan acara Rembuk Nasional 2009 untuk menentukan road-map pembangunan Indonesia. Acara Rembuk Nasional ini diselenggarakan di tengah munculnya skandal suap yang melibatkan Anggodo Widjojo, seorang pebisnis, dan beberapa pejabat tinggi Kepolisian RI (Polri) dan Kejaksaan Agung (Kejagung). Sebelum Komisi Pemberantasan Korupsi (KPK) bergerak untuk menyelidiki kasus suap ini, Polri dan Kejagung dengan cepat menahan Bibit Samad Riyanto dan Chandra Hamzah, dua pimpinan KPK, dengan tuduhan bahwa mereka telah menyalahgunakan kewenangan mereka. Tindakan Polri dan Kejagung ini mendapat protes keras dari seluruh masyarakat Indonesia yang melihatnya sebagai upaya pelemahan KPK oleh Polri dan Kejagung.

${ }^{40}$ Faisal Basri dan Haris Munandar, Op. Cit., hal. 20, 59-65,70. 
Skandal suap dan penahanan pimpinan KPK oleh Polri dan Kejagung ini telah mengalihkan perhatian masyarakat termasuk investor dari acara Rembuk Nasional 2009, walaupun acara tersebut berhasil menghasilkan beberapa program-program pembangunan yang penting. Masyarakat dan investor tidak peduli lagi dengan program pembangunan pemerintah, karena mereka tidak lagi percaya pada pemerintah yang tidak mampu untuk menghentikan korupsi di dalam lembaga-lembaganya. ${ }^{41}$

Masyarakat Indonesia dan investor kecewa oleh ketidak-tegasan dan keragu-raguan Presiden Yudhoyono untuk berpihak pada KPK dan menolak tindakan Polri dan Kejagung yang menahan kedua pimpinan KPK tersebut. Perintah Presiden Yudhoyono agar kasus penahanan dua pimpinan KPK oleh Polri diselesaikan di luar pengadilan (out of court settlement) telah diartikan oleh masyarakat sebagai keengganan Yudhoyono untuk tegas menegakkan hukum dan berperang melawan korupsi. Sikap Yudhoyono yang tidak tegas dalam skandal suap dan penahanan dua pimpinan KPK oleh Polri ini memberikan sinyal buruk pada investor akan tidak adanya kepastian hukum dan lemahnya penegakan hukum di Indonesia. Kasus ini telah menurunkan kepercayaan investor akan keamanan berinvestasi dan berbisnis di Indonesia. $^{42}$

Kasus lain di mana Presiden Yudhoyono juga enggan untuk menunjukkan dukungannya pada penegakan hukum adalah pada kasus Bank Century. Bank Century, atas rekomendasi dari Bank Indonesia, menerima dana talangan (bail-out) sebesar Rp. 6,762 trilyun dari Lembaga Penjamin Simpanan sewaktu bank tersebut mengalami gagal kliring dan menghadapi masalah likuiditas di bulan November 2008. Jumlah dana talangan yang luar biasa besar ini diberikan kepada Bank Century, walaupun sejak tahun 2005, Bank Indonesia dan Badan Pengawas Pasar Modal-Lembaga Keuangan (Bapepam-LK) telah

${ }^{41}$ Andi Suruji, Rembuk Nasional, Penahanan Pimpinan KPK dan Adam Smith, 31 Oktober 2009, dari <http://bisniskeuangan.kompas.com/read/xml/2009/10/31/05205849/ Rembuk.Nasional.dan.Adam.Smith>, diakses tanggal 3 April 2010. Lihat juga: Mumpung Besi Masih Membara", 1 Desember 2009, dari, <http://cetak.kompas.com/read/xml/2009/12/01/ 03081910/mumpung.besi.masih.membara>, diakses tanggal 3 April 2010.

42 Pasar Terpengaruh Kisruh KPK, 2 November 2009, dari $<$ http://bisniskeuangan.kompas.com/read/xml/2009/1 1/02/05385944/Pasar.Terpengaruh.Kisru h.KPK>, diakses tanggal 3 April 2010. Lihat juga: Polri Versus KPK Ganggu Investasi, 4 November 2009, dari <http://cetak.kompas.com/read/xml/2009/11/04/02573573/polri.versus. kpk.ganggu.investasi $>$, diakses tanggal 3 April 2010. 
menemukan adanya praktek kriminal penjualan reksa-dana fiktif di Bank Century yang mengakibatkan bank tersebut akhirnya mengalami masalah likuiditas. ${ }^{43}$ Sikap Yudhoyono dan partai Demokrat yang sejak semula tidak mendukung dilakukannya hak angket atas kasus dana talangan Bank Century oleh DPR, ${ }^{44}$ telah diinterpertasikan oleh masyarakat dan investor akan kembalinya era ketidak-pastian hukum dan korupsi di Indonesia.

\section{Kesimpulan}

Dari uraian di atas dapat disimpulkan bahwa di awal era Pemerintahan Reformasi, pemerintah telah berusaha melakukan reformasi hukum yang impresif dan telah berusaha mendudukkan hukum sebagai alat pembangunan ekonomi. Walau demikian, ternyata reformasi hukum yang dilakukan oleh Pemerintahan Reformasi ini masih mengandung banyak kelemahan, sehingga reformasi hukum tersebut gagal untuk mendorong pertumbuhan ekonomi di Indonesia.

Kelemahan dalam reformasi hukum tersebut antara lain berupa pelaksanaan otonomi daerah yang mengakibatkan ketidak-pastian hukum, karena masing-masing daerah di Indonesia mengeluarkan peraturanperaturan tentang pajak, retribusi, prosedur perizinan, yang saling tumpang tindih sehingga proses melakukan investasi di Indonesia menjadi rumit, makan waktu, dan berbiaya tinggi.

Kelemahan reformasi hukum lainnya adalah terlalu banyaknya peraturan yang dibuat oleh kementrian atau lembaga-lembaga pemerintahan yang saling bertentangan satu sama lainnya karena tidak adanya koordinasi di antara mereka. Terlalu banyaknya peraturan ini memaksa pelaku usaha untuk membayar biaya tidak resmi dan suap guna mempercepat proses perizinan dan clearance. Hal ini pada akhirnya menimbulkan ekonomi biaya tinggi bagi pelaku usaha.

${ }^{43}$ BI Tahu Kasus Bank Century Sejak 2005, 11 Februari 2009, dari $<$ http://bisniskeuangan.kompas.com/read/xml/2009/02/11/08161168/bi.tahu.kasus.bank.centur y.sejak.2005>, diakses tanggal 3 April 2010.

${ }^{44}$ Tanpa Partai Demokrat, Dukungan Hak Angket Capai 357 Orang, 30 November 2009, dari, <http://nasional.kompas.com/read/xml/2009/11/30/13465962/tanpa.partai. demokrat.dukungan.hak.angket.capai.357.orang>, diakses 3 April 2010. Lihat juga: Demokrat Tetap Tolak Angket Century, 14 November 2009, dari <http://www.republika.co.id/ berita/89401/Demokrat_Tetap_Tolak_Angket_Century>, diakses 3 April 2010. 
Kebiasaan pemerintah Reformasi untuk menerbitkan peraturanperaturan yang berlaku mundur (retroactive) juga merupakan kelemahan reformasi hukum. Peraturan-peraturan yang retroactive tersebut telah mengakibatkan ketidak-pastian hukum dan memunculkan konflik antara investor dan Pemerintah.

Sistem peradilan Indonesia yang sering mengingkari isi kontrak yang telah disepakati para pihak, serta tidak efektif untuk menagih kredit macet dan mengeksekusi agunan merupakan kelemahan lain dari reformasi hukum.

Sikap Presiden Yudhoyono yang tidak tegas dalam penegakan hukum dan pemberantasan korupsi di masa jabatannya yang kedua juga telah melemahkan reformasi hukum.

Kelemahan-kelemahan ini berakibat pada gagalnya peran hukum sebagai alat pembangunan ekonomi di Indonesia. Dengan tidak berperannya hukum dalam pembangunan ekonomi di Indonesia, pertumbuhan ekonomi Indonesia menjadi terhambat. Investor asing menghentikan investasinya di Indonesia karena ekonomi biaya tinggi dan tidak adanya jaminan kepastianhukum. Pelaku usaha juga semakin terbebani dengan biaya-biaya tidak resmi dan suap guna mempercepat proses perizinan, clearance, dan berbagai layanan pemerintah lainnya. Kalangan perbankan semakin enggan menyalurkan kredit pembiayaan pada sektor industri manufaktur karena ketidak-pastian hukum dan biaya tinggi dalam proses penagihan kredit macet dan eksekusi agunan. Hal ini berujung pada fenomena deindustrialisasi di Indonesia yang berbahaya bagi kestabilan sosial dan politik Indonesia.

Untuk mendorong pertumbuhan ekonomi Indonesia yang semakin memburuk ini, Pemerintahan Reformasi harus benar-benar menggunakan hukum sebagai alat pembangunan ekonomi, dan bukan lagi sebagai alat pencitraan atau retorika semata. 


\section{Daftar Pustaka}

\section{Buku}

Basri, Faisal dan Haris Munandar. Lanskap Ekonomi Indonesia, Jakarta: Kencana, 2009.

Ibrahim, Johnny. Pendekatan Ekonomi Terhadap Hukum. Teori dan Implikasi penerapannya dalam Penegakan Hukum. Surabaya: CV. Putra Media Nusantara \& ITS Press, 2009.

Linnan, David K. Insolvency Law and Institutions in Indonesia In Insolvency Law in East Asia, ed. Tomasic Roman. England: Ashgate, 2006.

Posner, Richard A. Economic, Analysis of Law, $7^{\text {th }}$ ed. Wolters Kluwer Law \& Business, 2007.

Weber, Max. Die Protestantische Ethik und der 'Geist' des Kapitalismus, (1905) diterjemahkan oleh Talcot Parsons, The Protestant Ethic and the Spirit of Capitalism. New York: Dover Publications, 2003.

\section{Jurnal, Artikel Ilmiah, Laporan Penelitian}

Asian Development Bank, Improving the Investment Climate in Indonesia. 2005.

KADIN Indonesia, Roadmap Pembangunan Ekonomi Indonesia 2009 2014. KADIN, 2009.

OECD, Economic Assessment of Indonesia 2008. OECD, 2008.

Porter, Michael E. dan Ketels, Christian, Indonesia: Attracting Foreign Investment. Harvard Business School, 2009.

Syaikhu Usman, et. al., Regional Autonomy and the Business Climate: Three Kabupaten Case Studies from North Sumatra. Indonesia: SMERU, 2001.

Syaikhu Usman, et. al., Regional Autonomy and the Business Climate: North Sulawesi and Gorontalo. Indonesia: SMERU, 2001.

The World Bank Group, Doing Business 2010 Report, June 2008 - May 2009 .

Trubek, David M. "Max Weber on Law and the Rise of Capitalism", Wisconsin Law Review, 3 (1972): 720-753. 
World Trade Organisation, Indonesia: December 1998. Trade Policy Reviews.

\section{Surat Kabar dan Majalah}

"Ekonomi Negara Tumbuh Tinggi Belum Cerminkan Adanya Efisiensi", KOMPAS, 21 October 1993.

"Era Masyarakat Industri Juga Perlu Jaminan Kepastian Hukum", KOMPAS, 15 September 1995.

"Hubungan Pusat-Daerah: Kewenangan Tumpang Tindih Menjadi Tidak Produktif', KOMPAS, 22 Mei 2009.

"Kasus Sony Harus Dijadikan Introspeksi", KOMPAS, 28 November 2002.

"Keinginan PMA Hengkang Perlu Diwaspadai", KOMPAS, 27 November 2002.

"Makna Pertumbuhan Tinggi Tetapi Tidak Efisien", KOMPAS, 22 October 1993.

"MTI: 79 Keppres Soeharto Menyimpang”, KOMPAS, 17 October 1998.

"Ribuan Perda Baru yang Bikin Pusing”, KOMPAS, 14 August 2003.

"Soeharto Defends Big Businesses", Jakarta Post, 30 Mei 1994.

"A World Bank Policy Research Report, The East Asian Miracle: Economic Growth and Public Policy", New York: Oxford University Press, 1993 in "Indonesia, Satu dari Delapan Negara dengan Keajaiban Pertumbuhan Ekonomi", KOMPAS, 18 Oktober 1993.

Himawan, Ch. "Hukum Macet. Penyebab Utama Kredit Macet", KOMPAS, 5 dan 6 Agustus 1993.

Surendro, Bramanian. "Perbankan Memiliki Struktur Oligopoly?", KOMPAS, 18 Mei 2009.

\section{Internet}

"Banyak Beban Aturan di Bea dan Cukai", 11 Juni 2008, $<$ http://www.kompas.com/printnews/xml/2008/06/11/04591538/ banyak.beban.aturan.di.bea.cukai>, diakses 28 Maret 2010. 
"Batu Bara Membara", 11 Agustus 2008, <http://cetak.kompas.com/ $\mathrm{read} / \mathrm{xml} / 2008 / 08 / 11 / 00570150 /$ batu.bara.membara>, diakses 28 Maret 2008.

"BI Tahu Kasus Bank Century Sejak 2005", 11 Februari 2009, $<\mathrm{http} / /$ bisniskeuangan.kompas.com/read/xml/2009/02/11/08161168/ bi.tahu.kasus.bank.century.sejak.2005>, diakses 3 April 2010.

"Demokrat Tetap Tolak Angket Century, 14 November 2009, $<$ http://www.republika.co.id/berita/89401/Demokrat_Tetap_Tolak_ Angket_Century>, diakses 3 April 2010.

"Dirjen Imigrasi Cekal 14 Pemimpin Perusahaan Tambang Batubara", 5 Agustus 2008, <http://www.kontan.co.id/index.php/nasional/news/ 626/Dirjen-Imigrasi-Cekal-14-Pemimpin-Perusahaan-TambangBatubara $>$, diakses tanggal 28 Januari 2010.

"Era Kontrak Karya Berakhir, Pengelolaan Pertambangan Lewat Perizinan", 17 Desember 2008, <http://cetak.kompas.com/read/xml/2008/12/17/ 00400686/era.kontrak.karya.berakhir>, diakses 28 Maret 2010.

"Kerja Keras Untuk Tumbuh 7 Persen", 26 Oktober 2009, , $<$ http://cetak.kompas.com/read/xml/2009/ 10/26/03245428/kerja.keras. untuk.tumbuh.7.persen>, diakses 3 April 2010.

"Kilas Ekonomi: Pemerintah Batalkan 2.097 Peraturan Daerah, 12 November 2009, dari <http://cetak.kompas.com/read/xml/2009/11/12/03061151/ kilas.ekonomi>, diakses 28 Maret 2010.

"LPS Harus Ganti Dana Nasabah Century", 10 Februari 2009, dari $<\mathrm{http} / / /$ bisniskeuangan.kompas.com/read/xml/2009/02/10/08105288/ lps.harus.ganti.dana.nasabah.century>, diakses 3 April 2010.

"MA Kabulkan Kasasi Prudential", 8 Juni 2004, <http://tempo.co.id/ hg/ekbis/2004/06/08/brk, 20040608-07,id.html>, diakses 3 April 2010.

"Manufaktur Tak Berkembang. Ekonomi Biaya Tinggi Jadi Salah Satu Penyebab", 8 Februari 2010, <http://cetak.kompas.com/read/xml/2010/ 02/08/03282498/manufaktur.tak.berkembang>, diakses 3 April 2010.

"Manulife Tak Jadi Bangkrut", 9 Juli 2002, <http://www.korantempo.com/ news/2002/7/9/Opini/ 83.html>, diakses 17 Juni 2009.

"Membendung Gejala Deindustrialisasi", 20 Oktober 2009, $<$ http://cetak.kompas.com/read/xml/2009/10/20/05135488/mem bendung.gejala.deindustrialisasi>, diakses 3 April 2010. 
"Menteri Keuangan Minta 1.651 Perda Dibatalkan", 21 Mei 2008, $<$ http://www.tempointeraktif.com/ hg/ekbis/2008/05/21/brk,20080521123439,id.html>, diakses 27 Maret 2010.

"Mumpung Besi Masih Membara", 1 Desember 2009, $<$ http://cetak.kompas.com/read/xml/2009/12/01/03081910/mumpung. besi.masih.membara>, diakses 3 April 2010.

"Pasar Terpengaruh Kisruh KPK", 2 November 2009, $<$ http://bisniskeuangan.kompas.com/read/xml/2009/11/02/05385944/ Pasar.Terpengaruh.Kisruh.KPK>, diakses 3 April 2010.

"Pelayanan BC di Priok Melambat", 20 Juni 2008, $<$ http://cetak.kompas.com/printnews/xml/2008/06/20/01035247/ pelayanan>, diakses tanggal 13 Agustus 2008.

"Pencekalan Pengusaha Batu Bara Dicabut", 10 Oktober 2008, $<$ http://www.republika.co.id/ koran/16/6793/Pencekalan_Pengusaha Batu_Bara_Dicabut>, diakses 10 Oktober 2008.

"Pengadilan Pailitkan Prudential Life", 23 April 2004, $<$ http://www.tempo.co.id/hg/hukum/2004/04/23/brk,20040423-35,id. html>, diakses 3 April 2010.

"Polri Versus KPK Ganggu Investasi", 4 November 2009, $<$ http://cetak.kompas.com/read/xml/2009/11/04/02573573/polri. versus.kpk.ganggu.investasi>, diakses 3 April 2010.

"Presiden Kembali Bantah", 2 Desember 2009, $<$ http://cetak.kompas.com/read/xml/2009/12/02/02404041/presiden. kembali.bantah>, diakses 8 Desember 2009.

"Prudential's Indonesian Directors Face Jail Threat Over Bankruptcy Charge", 11 Mei 2004, <http://www.financialexpress.com/printer/ news/59761/>, diakses 3 April 2010.

"Royalti Batu Bara, Presiden: Hindarkan Ketidakpastian Hukum", 14 Agustus 2008, <http://www.kompas.com/read/xml/2008/08/14/000 20617/presiden.hindarkan.ketidakpastian.hukum>, diakses 14 Agustus 2008.

"Tanpa Partai Demokrat, Dukungan Hak Angket Capai 357 Orang", 30 November 2009, <http://nasional.kompas.com/read/xml/2009/11/30/ 13465962/tanpa.partai.demokrat.dukungan.hak.angket.capai.357.orang >, diakses 3 April 2010. 
AFP. "Hong Kong Has Best Judicial System In Asia: Business", 14 September 2008, <http://afp.google.com/article/ALeqM5gIkKvkYnNQ1HVb2n_HUU MhncDLA>, diakses 27 Maret 2010.

Badan Perencanaan dan Pembangunan Nasional (BAPPENAS). "Wapres Panggil Menkeu Soal Manulife, Depkeu Kanada Protes ke Dubes RI", 18 Juni 2002, <http://els.bappenas.go.id/upload/other/Wapres\% 20Panggil\%20Menkeu\%20soal\%20Manulife.htm>, diakses 17 Juni 2009.

Friedman, David D. "Law and Economics 2002", <http://www.econlib.org/ library/Enc1/LawandEconomics.html>, diakses 27 Maret 2010.

Himawan, Ch. "Mercu Suar Hukum Bagi Pelaku Ekonomi (Bagian II)", 21 April 1998, <http://www.kompas.com/9804/21/EKONOMI/ merc09.html>, diakses 21 April 1998.

Suruji, Andi. "Rembuk Nasional, Penahanan Pimpinan KPK dan Adam Smith", 31 Oktober 2009, <http://bisniskeuangan.kompas.com/read/ xml/2009/10/31/05205849/Rembuk.Nasional.dan.Adam.Smith>, diakses 3 April 2010.

Tajuk Rencana: "Deindustrialisasi Kian Nyata", 8 Oktober 2009,; dari $<$ http://cetak.kompas.com/read/xml/2009/10/08/02461119/tajuk. rencana>, diakses 3 April 2010.

Utomo, St Laksanto. "Menyoal Eksekutorial Hak Tanggungan", Antara News, 1 Januari 2009, dari <http://www.antara.co.id/print/1230784 015>, diakses 3 April 2010. 